\title{
Analysis Of The Effect Of One Phase Open Stator On The Performance And Temperature Of A Three Phase Induction Motor Cage Rotor
}

\author{
Christover Pasaribu \\ Department Of Electrical Engineering, University Of North Sumatra, Jl. Dr. Mansur No. 9 Padang Bulan, Kec. \\ Medan Baru, Kota Medan 20222
}

\begin{tabular}{|c|c|}
\hline ARTICLE INFO & ABSTRACT \\
\hline Article history: & \multirow{4}{*}{$\begin{array}{l}\text { Induction motors are alternating current motors that are most often } \\
\text { used in the industrial world. Induction motors are used as pumps, } \\
\text { compressors, fans, conveyors, and supporting other production } \\
\text { propulsion equipment. The use of induction motors in industry is } \\
\text { more profitable than DC motors or synchronous motors, one of the } \\
\text { advantages is a strong and durable construction and easy } \\
\text { maintenance and high efficiency. The problem of one of the open } \\
\text { stator phases is one of the problems in the operation of an induction } \\
\text { motor. Therefore, it is necessary to conduct a study in the form of } \\
\text { analysis and research in the laboratory to see how the opening of } \\
\text { one of the stator phases affects the performance and temperature } \\
\text { rise of the induction motor. The test is carried out by overloading the } \\
\text { induction motor by } 0.5 \mathrm{Nm} \text {; } 1.0 \mathrm{Nm;} 1.5 \mathrm{Nm} \text {; } 2.0 \mathrm{Nm} ; 2.5 \mathrm{Nm} ; 3.0 \\
\text { Nm. From the research conducted, it can be concluded that, among } \\
\text { others, the opening of a single stator phase results in greater motor } \\
\text { losses and an increase in motor temperature. Motor efficiency is } \\
\text { better when the motor is in normal phase condition. }\end{array}$} \\
\hline $\begin{array}{r}\text { Received Feb 05, } 2020 \\
\text { Revised Mar 13, } 2020 \\
\text { Accepted Apr 30, } 2020\end{array}$ & \\
\hline Keywords: & \\
\hline $\begin{array}{l}\text { Induction Motor } \\
\text { Stator Phase Open }\end{array}$ & \\
\hline
\end{tabular}

This is an open access article under the CC BY-NC license.

\section{Corresponding Author:}

Christover Pasaribu,

Department Of Electrical Engineering,

University Of North Sumatra,

JI. Dr. Mansur No. 9 Padang Bulan, Kec. Medan Baru, Kota Medan 20222.

Email : christoverpasaribu@gmail.com

\section{INTRODUCTION}

Induction motors are alternating current motors that are most often used in the industrial world. Induction motors are used as pumps, compressors, fans, conveyors, and supporting other production propulsion equipment. This is because the induction motor is very easy to operate. In addition, induction motors have a strong construction, are durable, and easy to maintain, and have good efficiency.

Due to something, such as lack of maintenance and an old machine, it will cause one of the stator phases to be damaged or not functioning, or the source voltage from the panel to lose one of its phases. The loss of one phase will affect the machine's ability to work optimally. The loss of one phase will also cause interference with the current and voltage of the motor, this of course will result in an increase in heat in the motor.

Therefore, it is necessary to conduct a study in the form of analysis and research in the laboratory to see how a situation where one phase of the stator is open in a three-phase induction 
motor affects changes in temperature and the performance of the three-phase induction motor itself.

\section{RESEARCH METHOD}

\subsection{Research procedure}

The research will be conducted to obtain the value of voltage, current, rotation, and power factor in a normal three-phase induction motor and an open single-phase stator. The experiment will be conducted at the Electric Motor Laboratory, Center for the Development and Empowerment of Educators and Education Personnel in the Building and Electrical Sector (P4TK).

\subsection{Three Phase Induction Motor Parameter Experiment}

To calculate the efficiency and losses in the induction motor, it is necessary to know several parameters of the induction motor. There were three experiments carried out to obtain the required induction machine parameters, namely: Stator Resistance Measurement Experiment (DC test), Zero Load Experiment, and Short Circuit Experiment (restrained rotor).

\section{a. Three Phase Induction Motor Experiment Normal Phase Condition}

Trial Procedure:

1) A three-phase induction motor is coupled to a servo, then the experimental circuit is assembled.

2) All switches are open.

3) The switch on the Power Supply Electric Machine is closed, then the motor is run by pressing the ON button on the Power Switch. The stopwatch timer is started to determine the motor operating time.

4) The motor is run with varying load (torque). In this experiment the selected load is: $0 \mathrm{Nm}$; $0.5 \mathrm{Nm} ; 1 \mathrm{Nm} ; 1.5 \mathrm{Nm} ; 2 \mathrm{Nm} ; 2.5 \mathrm{Nm} ; 3 \mathrm{Nm}$.

5) To adjust the load, the RUN button is pressed and the selector on the Servo Machine Test System is rotated until the torque gauge shows the desired load, $0 \mathrm{Nm}-3 \mathrm{Nm}$.

6) Recorded experimental data (voltage, current, power, power factor) displayed on the Three Phase Meter for each selected load.

7) The motor is run with varying load (torque). In this experiment the selected load is: $0 \mathrm{Nm}$; $0.5 \mathrm{Nm} ; 1 \mathrm{Nm} ; 1.5 \mathrm{Nm} ; 2 \mathrm{Nm} ; 2.5 \mathrm{Nm} ; 3 \mathrm{Nm}$.

8) To adjust the load, the RUN button is pressed and the selector on the Servo Machine Test System is rotated until the torque gauge shows the desired load, $0 \mathrm{Nm}-3 \mathrm{Nm}$.

9) Recorded experimental data (voltage, current, power, power factor) displayed on the Three Phase Meter for each selected load children

\section{RESULTS AND DISCUSSIONS}

\subsection{General}

The induction motor is the most widely used type of motor in industry. Induction motors are widely used as pumps, compressors, fans, conveyors, and supporting other production propulsion equipment. The number of uses of this motor is based on the fact that induction motors are more profitable than synchronous motors and DC motors. This is because induction motors have simple construction, are durable, easy to maintain, and have high efficiency.

During its operation, induction motors cannot be separated from problems, both technical and non-technical. The opening of one of the stator phases is one of the problems in the operation of an induction motor. This can be caused by various asymmetry disturbances in the system.

In this chapter, we will discuss the effect of the opening of one of the stator phases on the performance and temperature of a three-phase induction motor. The performance and temperature of an induction motor under normal phase conditions will be compared with the performance and temperature of an induction motor in an open stator phase.

\subsection{Trial Data}


From the results of research conducted at the Electric Motor Laboratory, the Center for the Development and Empowerment of Educators and Education Personnel in the Construction and Electrical Sector (P4TK), the following test data were obtained.

\subsection{Three Phase Induction Motor Parameter Experiment}

To determine the parameters of the induction motor, there are 3 experiments carried out, namely the stator resistance measurement experiment (DC test), zero load experiment, and the rotor restraint experiment (short circuit).

\subsection{Three Phase Induction Motor Experiment Normal Phase Condition}

From the tests conducted at the Electric Motor Laboratory of the Center for the Development and Empowerment of Educators and Education Personnel (P4TK) in the Construction and Electrical Sector, the phase-to-phase voltage (VL-L) from the grid is the same as the voltage of the PLN secondary distribution network, which is 380 Volts. Therefore the stator winding is connected wye $(Y)$. By running a three-phase induction motor under normal phase conditions, the following data are obtained.
a. VLL : 380 Volt
b. Relationship : $\mathrm{Y}$ (wye)
c. To: 28.9 oC

Table 1. Induction motor test results data normal phase condition

\begin{tabular}{cccccrc}
\hline $\begin{array}{c}\text { Burden } \\
(\mathrm{Nm})\end{array}$ & $\begin{array}{c}\text { Voltage } \\
\text { (Volt) }\end{array}$ & $\begin{array}{c}\text { Current } \\
\text { (ampere) }\end{array}$ & $\begin{array}{c}\text { Power } \\
(\text { Watt })\end{array}$ & $\begin{array}{c}\text { Factor } \\
\text { Power }\end{array}$ & $\begin{array}{c}\text { Round } \\
(\mathrm{nr})(\mathrm{rpm})\end{array}$ & $\begin{array}{c}\text { Tempera } \\
\text { ture } \\
(\mathrm{oC})\end{array}$ \\
\hline 0 & 380 & 2.0 & 223.78 & 0.17 & 2999 & 31.2 \\
0.5 & 380 & 2.1 & 414.65 & 0.3 & 2979 & 33.4 \\
1.0 & 380 & 2.15 & 608.49 & 0.43 & 2965 & 34.0 \\
1.5 & 380 & 2.25 & 755.26 & 0.51 & 2949 & 35.4 \\
2.0 & 380 & 2.35 & 912.57 & 0.59 & 2923 & 36.1 \\
2.5 & 380 & 2.49 & 1081.65 & 0.66 & 2903 & 37.2 \\
3.0 & 380 & 2.68 & 1252.38 & 0.71 & 2878 & 38.1 \\
\hline
\end{tabular}

\subsection{Three Phase Induction Motor Experiment Single Phase Stator Open Condition}

From the tests carried out at the Electric Motor Laboratory of the Center for the Development and Empowerment of Educators and Education Personnel (P4TK) in the Construction and Electrical Sector, the phase-to-phase voltage (VLL) of the grid is 380 Volts.

By running a three-phase induction motor in an open single-phase condition, the following data are obtained.
a. VLL : 380 Volt
b. Relationship : Y (wye)
c. To: 29 oC

Table 2. Data from the test results of an induction motor with a single phase stator open

\begin{tabular}{ccccccc}
\hline $\begin{array}{c}\text { Burden } \\
(\mathrm{Nm})\end{array}$ & $\begin{array}{c}\text { Voltage } \\
(\text { Volt })\end{array}$ & $\begin{array}{c}\text { Current } \\
(\text { ampere })\end{array}$ & $\begin{array}{c}\text { Power } \\
(\text { Watt })\end{array}$ & $\begin{array}{c}\text { Factor } \\
\text { Power }\end{array}$ & $\begin{array}{c}\text { Round } \\
(\mathrm{nr})(\mathrm{rpm})\end{array}$ & $\begin{array}{c}\text { Temperature } \\
(\mathrm{oC})\end{array}$ \\
\hline 0 & 380 & 2.90 & 297.54 & 0.27 & 2997 & 32.2 \\
0.5 & 380 & 2.96 & 404.93 & 0.36 & 2973 & 34.6 \\
1.0 & 380 & 3.13 & 582.81 & 0.49 & 2957 & 35.7 \\
1.5 & 380 & 3.29 & 725,12 & 0.58 & 2938 & 37.2 \\
2.0 & 380 & 3.41 & 842.27 & 0.65 & 2912 & 38.3 \\
2.5 & 380 & 3.51 & 947.00 & 0.71 & 2879 & 40.6 \\
3.0 & 380 & 3.70 & 1110.74 & 0.79 & 2856 & 41.5 \\
\hline
\end{tabular}

\subsection{Analysis and Calculation of Loss and Efficiency of Induction Motors in Normal Phase Conditions}


In this chapter, the losses and efficiency of induction motors are calculated under normal phase conditions. This data analysis aims to obtain the value of the comparison of losses and motor efficiency under normal phase conditions and the condition of an open stator single phase. For this reason, the authors take the example of calculations at a load of $0.5 \mathrm{Nm}$.

From the experiment for a load of $0.5 \mathrm{Nm}$ under normal phase conditions, the following data were obtained.

$\begin{array}{ll}\mathrm{V} & : 380 \text { Volt } \\ \mathrm{I} & : 2.1 \text { Ampere } \\ \text { Cos } & : 0.3 \\ \mathrm{nr} & : 2979 \mathrm{rpm} \\ \text { R stator } & : 4.4 \\ \text { R rotor } & : 4.84 \\ \text { Pole }(\mathrm{p}) & : 2\end{array}$

By doing the same calculation, the total motor losses and motor efficiency will be obtained for a load of $1 \mathrm{Nm} ; 1.5 \mathrm{Nm} ; 2 \mathrm{Nm} ; 2.5 \mathrm{Nm} ; 3 \mathrm{Nm}$. The results of the calculations carried out are arranged in table 3 as follows.

Table 3 The data from the calculation of the induction motor in normal phase conditions

\begin{tabular}{ccccccccccc}
\hline $\begin{array}{c}\text { Burden } \\
(\mathrm{Nm})\end{array}$ & $\begin{array}{c}\text { Vin } \\
(\mathrm{V})\end{array}$ & $\begin{array}{l}\text { lin } \\
(\mathrm{A})\end{array}$ & Pin (W) & Pf & $\begin{array}{c}\mathrm{Nr} \\
(\mathrm{rpm})\end{array}$ & slip & $\begin{array}{c}\text { Pout } \\
(\mathrm{W})\end{array}$ & $\begin{array}{c}\text { Ploss } \\
(\mathrm{W})\end{array}$ & $\begin{array}{c}\square \\
(\%)\end{array}$ & $\begin{array}{c}\mathrm{T} \\
(\mathrm{oC})\end{array}$ \\
\hline 0 & 380 & 2.0 & 223.78 & 0.17 & 2999 & 0.0003 & - & - & - & 31.2 \\
0.5 & 380 & 2.1 & 414.65 & 0.3 & 2979 & 0.007 & 179.45 & 235,20 & 43.28 & 33.4 \\
1.0 & 380 & 2.15 & 608.49 & 0.43 & 2965 & 0.0117 & 365.34 & 243.15 & 60.04 & 34 \\
1.5 & 380 & 2.25 & 775.26 & 0.51 & 2949 & 0.0170 & 502.74 & 252.52 & 66.57 & 35.4 \\
2.0 & 380 & 2.35 & 912.57 & 0.59 & 2923 & 0.0257 & 646.33 & 266.24 & 70.83 & 36.1 \\
2.5 & 380 & 2.49 & 1081.65 & 0.66 & 2903 & 0.0323 & 799.13 & 282.52 & 73.88 & 37.2 \\
3.0 & 380 & 2.68 & 1252.38 & 0.71 & 2878 & 0.0407 & 948.29 & 304.09 & 75.72 & 38.1 \\
\hline
\end{tabular}

To make it easier to understand and analyze the calculated data, the calculation results are shown in the following graph.

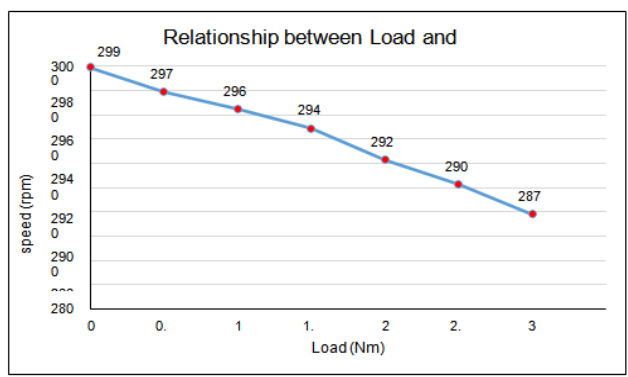

Figure 1. Graph of load vs speed of induction motor under normal phase conditions

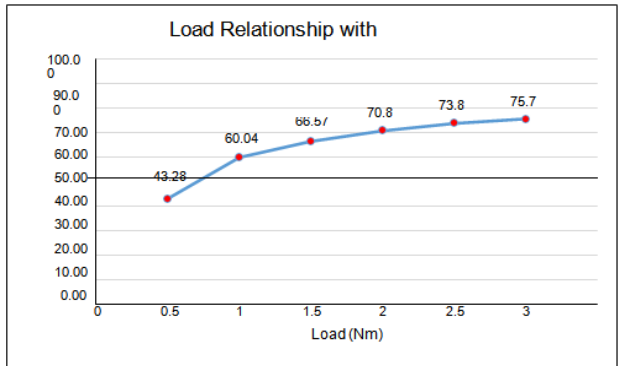

Figure 2. Graph of load vs. efficiency of induction motor under normal phase conditions 


\subsection{Analysis and Calculation of Loss and Efficiency of Induction Motors in Single Phase Stator Open Conditions}

In this chapter, the losses and efficiency of an induction motor are calculated in an open stator single-phase condition. This data analysis aims to obtain the value of the loss-loss ratio and the efficiency of the motor under normal and single-phase conditions with an open stator.

The author takes the example of calculations at a load of $0.5 \mathrm{Nm}$, at this load the following data are obtained.

\begin{tabular}{|c|c|}
\hline V & $=380$ Volts \\
\hline I & $=2.96$ Ampere \\
\hline Cos & $=0.36$ \\
\hline $\mathrm{nr}$ & $=2973$ \\
\hline R stator & $=4.4$ \\
\hline $\mathrm{R}$ rotor & $=4.84$ \\
\hline Pole (p) & $=2$ \\
\hline
\end{tabular}

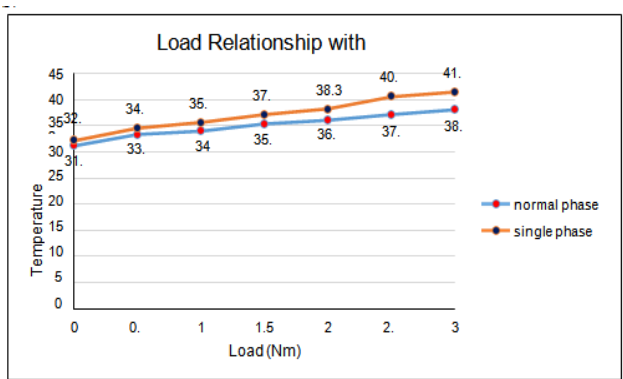

Figure 3. Graph of load vs. temperature induction motor under normal phase conditions and single phase stator open conditions

The state of an open single-phase stator causes a decrease in the speed of the induction motor, this can be seen in Figure 1. Motors become more vibrates and is noisier than the normal phase state, this is due to the uneven torque generated in the motor. Through Figure 2, it can be seen that the value of the efficiency of an induction motor with a single phase stator open is smaller than the normal state. This is caused by an increase in the value of induction motor losses, it can be seen in Figure 3 where the induction motor losses in an open stator phase are greater than the normal phase.

In Figure 3 it can be seen that the temperature value of the induction motor in the open state of the single phase stator is greater than the normal phase state. An open stator single-phase induction motor experiences overheating which can cause winding damage if the motor continues to operate.

\section{CONCLUSION}

The opening of a single stator phase in an induction motor will affect the performance of the induction motor. At a load of $3 \mathrm{Nm}$, the current under normal phase conditions is 2.68 Ampere; temperature of $38.10 \mathrm{C}$; power factor of 0.71 ; and the motor rotation is $2878 \mathrm{rpm}$, while in the condition of one phase the stator is open, the current is 3.70 Ampere; temperature of $41.50 \mathrm{C}$; power factor of 0.79 ; and motor rotation of $2856 \mathrm{rpm}$.

At a load of $3 \mathrm{Nm}$, the motor losses under normal phase conditions are 304.09 Watts and in an open single phase stator, the motor losses are 402.78 Watts.

The opening of one stator phase will affect the efficiency of the induction motor. From the calculation results, at a load of $3 \mathrm{Nm}$, the efficiency of the motor under normal phase conditions is 
$75.72 \%$ and in the condition of an open single-phase stator, the efficiency of the motor becomes $65.71 \%$.

\section{REFERENCES}

Chapman, Stephen J., "Electric Machinery Fundamentals", Fourth Edition, McGraw-Hill, New York, 2005.

Fitzgerald, A.E., Kingsley, C.Jr., Umans, S.D., "Electric Machinery", Sixth Edition, McGraw-Hill, New York, 2003.

Jr, Stevenson \& D. William, "Analisa Sistem Tenaga”, Edisi Keempat, McGraw- Hill. Terjemahan : Penerbit Erlangga, 1983.

Lister, E.C., "Electric Circuit and Machines", Sixth Edition, Mc Graw-Hill, 1984. Terjemahan : Gunawan, H., "Mesin dan Rangkaian Listrik", Penerbit Erlangga.

Theraja, B.L. \& Theraja A.K., "A Textbook of Electrical Technology", Volume II, S.Chand, New Delhi, 2001.

Wildi, Theodore, "Electrical Machines, Drives and Power Systems", Sixth Edition, Pearson Prentice Hall, New Jersey, 2006.

Zuhal, “Dasar Teknik Tenaga Listrik dan Elektronika Daya”, Edisi Kelima, Penerbit Gramedia, Jakarta, 1995. 